\title{
Copper-enriched Palladium-Copper alloy nanoparticles for effective electrochemical formic acid oxidation
}

Qi Zhao, ${ }^{[\mathrm{a}]}$ Juan Wang, ${ }^{[\mathrm{a}]}$ Xing Huang, ${ }^{[\mathrm{b}]}$ Yuanying Yao, ${ }^{[\mathrm{a}]}$ Wei Zhang, ${ }^{[\mathrm{c}]}$ and Lidong Shao*[a]

a Qi. Zhao, Dr. J. Wang, Y.Y. Yao, Dr. L.D. Shao

Shanghai Key Laboratory of Materials Protection and Advanced Materials in Electric Power, Shanghai University of Electric power, Shanghai 200090, China.

E-mail: lidong.shao@shiep.edu.cn

b Dr. X. Huang

Department of Inorganic Chemistry, Fritz-Haber Institute of the Max Planck Society, Faradayweg 4-6, 14195 Berlin, Germany

E-mail: xinghuang@fhi-berlin.mpg.de

c Dr. W. Zhang

CIC Energigune, Parque Tecnológico de Álava, Miñano 01510, and Ikerbasque, Basque Foundation for Science, Bilbao 48011, Spain

Abstract: In this work, Pd-Cu alloy nanoparticles (NPs) with different atomic ratios are prepared on functionalized carbon nanotubes (CNTs) and applied as electrocatalysts for formic acid oxidation. The $\mathrm{Cu}$-enriched $\mathrm{Pd}-\mathrm{Cu}$ alloy NPs exhibit improved electrocatalytic activity and stability. Functionalized carbon supports are applied as substrates to tune the nanoscale morphologies of the obtained bimetallic phases under appropriate calcination and hydrogenation treatments. Spill-over effect aids a reduction of a high weight loading of $\mathrm{Cu}$ in its metallic phase, in turn, these $\mathrm{Cu}$ atoms integrate into Pd lattice and isolate Pd neighboring atoms. Surface analyses show that a certain amount of the isolated Pd remains on the surfaces of Pd-Cu alloy NPs, which is responsible for the enhanced electrocatalytic performance.

Keywords: formic acid, Copper-enriched, Palladium-Copper alloy, carbon nanotube

\section{Introduction}


In recent years, formic acid, which represents a new feedstock for fuel cells, has been widely investigated because it is non-toxic and exhibits a low crossover rate through Nafion membranes. Direct formic acid fuel cells (DFAFCs) have favourable oxidation kinetics, low operating temperatures, and high theoretical open-circuit potentials, and they effectively overcome the $\mathrm{H}_{2}$-storage and transport problems associated with proton-exchange membrane fuel cells (PEMFCs) and the toxicity of the methanol used in direct methanol fuel cells (DMFCs). Thus, they open up a pathway for the development of a new type of portable power[1-3].

Currently, the catalytic materials that are most commonly used as fuel cell anodes are Pt-based alloys[4,5]. However, Pt resources are limited, expensive, and prone to carbon monoxide $(\mathrm{CO})$ poisoning, and thus, the application of Pt catalysts is limited[3,6,7]. Pd and Pt are elements of the same group and have similar characteristics, including face-centred cubic (fcc) crystal structures and similar atomic sizes. Pd-based catalysts are considered to be better electrocatalysts than Pt-based ones because the reaction on the Pd surface follows a direct pathway. Nevertheless, the inferior electrocatalytic stability of Pd catalysts has limited their development[8]. Introducing structural modifications by adding foreign atoms to generate Pd-based alloys has been investigated to enhance the catalytic activity at low overpotentials and increase the stability of Pd-based catalysts. However, the practical application of Pd-based alloys as electrocatalysts for DFAFCs remains challenging. First, Pd and other added metals have been reported to exceed $20-30 \mathrm{wt} \%[9,10]$. Using this amount of metals prohibits the metal dispersion in nanoscale and limits the accessible 
surface areas during catalysis. Second, the effects of the surface electronic properties and structural stabilities of bimetallic compounds (controlled by bonding patterns) on $\mathrm{HCOOH}$ oxidation remain unclear.

Herein, $\mathrm{Pd}-\mathrm{Cu}$ alloys with various $\mathrm{Pd}: \mathrm{Cu}$ molar ratios are fabricated on carbon nanotubes $\left(\mathrm{Pd}_{\mathrm{x}} \mathrm{Cu}_{\mathrm{y}} / \mathrm{CNTs}\right)$ for catalytic studies in $\mathrm{HCOOH}$ oxidation. Functionalized CNTs embed nanocrystals of the formed alloy particles and facilitate their nanoscale dispersion during calcination and reduction treatments. The $\mathrm{HCOOH}$ oxidation results indicate that $\mathrm{Cu}$-enriched $\mathrm{Pd}-\mathrm{Cu}$ alloy NPs exhibit enhanced activity and stability relative to the other $\mathrm{Pd}_{\mathrm{x}} \mathrm{Cu}_{\mathrm{y}}$ alloys with lower $\mathrm{Cu}$ contents. Furthermore, surface and structural analyses reveal that the surface electronic properties of $\mathrm{Cu}$-enriched $\mathrm{Pd}-\mathrm{Cu}$ alloy NPs may govern the catalytic pathways.

\section{Materials and methods}

PR24 low-heat-treated (LHT) CNTs (1g) were functionalized by oxidation in concentrated $\mathrm{HNO}_{3}(300 \mathrm{~mL})$ for $1 \mathrm{~h}$ at $120^{\circ} \mathrm{C}[11] . \mathrm{Pd}_{\mathrm{x}} \mathrm{Cu}_{\mathrm{y}} / \mathrm{CNTs}$ (where $\mathrm{x}: \mathrm{y}=1: 0$, 3:1, 1:1, 1:3, or $0: 1)$ were synthesized as following: in the case of $\operatorname{Pd}_{1} \mathrm{Cu}_{3} / \mathrm{CNTs}, 31.8$ $\mu \mathrm{L}$ of $\mathrm{Pd}\left(\mathrm{NO}_{3}\right)_{2} \quad(10 \quad \mathrm{wt} \%$, Sigma-Aldrich $)$ solution, $11.2 \mathrm{mg} \quad \mathrm{Cu}\left(\mathrm{NO}_{3}\right)_{2}$ (Sigma-Aldrich) were mixed into $20 \mathrm{ml}$ ethanol, followed by adding $50 \mathrm{mg}$ of CNTs to allow coordination with functionalities as anchoring sites. Stirring was maintained at $45^{\circ} \mathrm{C}$ throughout the impregnation process until the solution had dried. The collected powder was calcined in a muffle for $2 \mathrm{~h}$ at $250^{\circ} \mathrm{C}$ and then annealed in a tube furnace for $2 \mathrm{~h}$ at $250^{\circ} \mathrm{C}$ under a $\mathrm{He} / \mathrm{H}_{2}$ atmosphere $\left(\mathrm{He}, 100 \mathrm{~mL} / \mathrm{min} ; \mathrm{H}_{2}, 25 \mathrm{~mL} / \mathrm{min}\right)$. 
of real metal weight percentages in the alloy NPs were measured by the inductively coupled plasma atomic emission spectroscopy (ICP): $\mathrm{Pd} / \mathrm{CNTs}(3.25 \mathrm{wt} \%), \mathrm{Pd}_{1} \mathrm{Cu}_{3}(\mathrm{Pd}$ $3 w t \%, \mathrm{Cu} 5.25 w t \%), \mathrm{Pd}_{1} \mathrm{Cu}_{1}(\mathrm{Pd} 2.8 w t \%, 1.6 w t \%), \mathrm{Pd}_{3} \mathrm{Cu}_{1}(\mathrm{Pd} 2.8 w t \%, \mathrm{Cu} 0.7 \mathrm{wt} \%)$. The weight percent of $\mathrm{Cu}$ in $\mathrm{Cu} / \mathrm{CNTs}$ was $3 \mathrm{wt} \%$. X-ray diffraction (XRD) was performed using a Bruker D8 Advance XRD instrument with $\mathrm{Cu}-\mathrm{K} \alpha$ radiation. An aberration-corrected JEOL JEM-ARM200CF transmission electron microscope was employed to investigate structural and chemical properties in STEM mode. X-ray photoelectron spectroscopy (XPS) was conducted with a Thermo ESCALAB 250 XPS instrument using a monochromatic Al Ka source $(1486.6 \mathrm{eV})$.

\section{Results and Discussion}

Fig. 1a shows the dispersion of $\mathrm{Pd}-\mathrm{Cu}$ NPs on the $\mathrm{Pd}_{1} \mathrm{Cu}_{3} / \mathrm{CNT}$. Fig. 1b presents the high-resolution scanning TEM (HR-STEM) image of a Pd-Cu alloy NP on the $\mathrm{Pd}_{1} \mathrm{Cu}_{3} / \mathrm{CNTs}$. The HR-STEM image shows that the interplanar distances were 0.220 $\mathrm{nm}$ and presents two sets of (111) planes with an acute angle $70.5^{\circ}$. Fig. 1c is the STEM image of dispersed Pd-Cu alloy NP on the $\mathrm{Pd}_{1} \mathrm{Cu}_{3} / \mathrm{CNT}$, and Figs. 1 (d-e ) present the STEM-energy-dispersive X-ray spectroscopy (EDX) element mapping distributions of $\mathrm{Pd}$ and $\mathrm{Cu}$, respectively. Based on the STEM-EDX elemental mapping, $\mathrm{Cu}$ and $\mathrm{Pd}$ are homogeneously distributed within the NPs. Fig. 1 indicates the alloying states of the nanocatalysts. The lattice parameters of fcc $\mathrm{Pd}$ and $\mathrm{Cu}$ metals are 0.226 and $0.208 \mathrm{~nm}$, respectively, and the lattice parameters of the alloying NPs fall between these values. 
Fig. 2 shows the XRD patterns of the $\mathrm{Pd} / \mathrm{CNTs}, \mathrm{Pd}_{\mathrm{x}} \mathrm{Cu}_{\mathrm{y}} / \mathrm{CNTs}$, and $\mathrm{Cu} / \mathrm{CNTs}$ samples. The $\mathrm{Pd} / \mathrm{CNTs}$ sample shows peaks at $40.1^{\circ}(\operatorname{Pd}(111)), 46.7^{\circ}(\operatorname{Pd}(200))$, and $68.1^{\circ}(\operatorname{Pd}(220))$, suggesting the synthesis of Pd NPs (JCPDS standard Pd 46-1043). The $\mathrm{Cu} / \mathrm{CNTs}$ sample shows peaks at $43.3^{\circ}(\mathrm{Cu}(111))$ and $50.4^{\circ}(\mathrm{Cu}(200))$, indicating the synthesis of $\mathrm{Cu}$ NPs (JCPDS standard 04-0836(Cu)). The peaks located at $\sim 42.8^{\circ}$ for the $\mathrm{Pd}_{1} \mathrm{Cu}_{1} / \mathrm{CNTs}, \mathrm{Pd}_{3} \mathrm{Cu}_{1} / \mathrm{CNTs}$, and $\mathrm{Pd} / \mathrm{CNTs}$ samples correspond to the $\mathrm{C}(101)$ reflection planes of carbon (JCPDS standard C 26-1077). Fig. 2(b-d) show that the Pd peaks broaden and the $2 \theta$ angles increase from 40.1 to $41.4^{\circ}$ as the $\mathrm{Cu}$ content increases, indicating that the $\mathrm{Cu}$ atoms have entered the Pd crystal to generate a fcc Pd-Cu alloy structure[12, 13]. It should be noted that systems containing two or more metallic species may exist in several phases. The $\mathrm{Pd}_{1} \mathrm{Cu}_{3} / \mathrm{CNTs}$ show a perturbation peak at $41.3^{\circ}$, indicating that a $\mathrm{PdCu}$ intermetallic phase (JCPDS standard 48-1551 (CuPd)) may have formed within the $\mathrm{Pd}_{1} \mathrm{Cu}_{3} / \mathrm{CNTs}$ sample.

XPS was further utilized to examine the surface compositions and valence electronic structures of $\mathrm{Pd}_{\mathrm{x}} \mathrm{Cu}_{\mathrm{y}} / \mathrm{CNTs}$ catalysts. Upon addition of $\mathrm{Cu}$, the original $\mathrm{Pd}$ peak profile is gradually weakened (Fig. 3A). However, the preserved $\mathrm{Pd} 3 \mathrm{~d}$ spectra on all the $\mathrm{Pd}_{\mathrm{x}} \mathrm{Cu}_{\mathrm{y}} / \mathrm{CNTs}$ indicates that some $\mathrm{Pd}$ in monometallic phase remains dispersed on the catalyst surfaces. On the other hand, Fig. 3B shows a higher $\mathrm{Cu}^{0}$ peak on the $\mathrm{Pd}_{1} \mathrm{Cu}_{3} / \mathrm{CNTs}$ than on the $\mathrm{Cu} / \mathrm{CNTs}$. Owning to the fact that more $\mathrm{Cu}$ (5.3wt.\%) is present in $\mathrm{Pd}_{1} \mathrm{Cu}_{3} / \mathrm{CNTs}$ than in $\mathrm{Cu} / \mathrm{CNTs}$ (3wt.\%), we propose that the enhanced $\mathrm{Cu}^{0}$ peak on $\mathrm{Pd}_{1} \mathrm{Cu}_{3} / \mathrm{CNTs}$ was caused by the spillover effect. In this process, the $\mathrm{H}_{2}$ adsorbed on the noble metal surfaces decomposes to $\mathrm{H}$ atoms, and 
these dissociative $\mathrm{H}$ atoms migrate to alloyed metals or supporting oxides[14,15]. Accordingly, spill-over effects is known to exert significant influences in the field of heterogeneous catalysis by shaping and affecting the supported active phases[16].

The catalytic activities of these $\mathrm{Pd}_{\mathrm{x}} \mathrm{Cu}_{\mathrm{y}} / \mathrm{CNTs}$ catalysts were investigated by cyclic voltammetry (CV). Fig. 4A shows the mass activities of $\mathrm{Pd}_{\mathrm{x}} \mathrm{Cu}_{\mathrm{y}} / \mathrm{CNTs}$ catalysts for formic acid electrooxidation. The potentials of both $\mathrm{Pd}_{1} \mathrm{Cu}_{3} / \mathrm{CNTs}$ and $\mathrm{Pd} / \mathrm{CNTs}$ are $0.15 \mathrm{~V}$, whereas those of both $\mathrm{Pd}_{3} \mathrm{Cu}_{1} / \mathrm{CNTs}$ and $\mathrm{Pd}_{1} \mathrm{Cu}_{1} / \mathrm{CNTs}$ are $0.14 \mathrm{~V}$.

No obvious difference was noticed in the anodic peak potential. For comparison, the mass activity of $\mathrm{Pd}_{1} \mathrm{Cu}_{3} / \mathrm{CNTs}$ is $560 \mathrm{~A} \mathrm{~g}^{-1}$, whereas that of $\mathrm{Pd} / \mathrm{CNTs}$ is $487 \mathrm{~A} \mathrm{~g}^{-1}$. Thus, the $\mathrm{Pd}_{1} \mathrm{Cu}_{3} / \mathrm{CNT}$ s catalyst is more active than the $\mathrm{Pd} / \mathrm{CNT}$ catalyst for formic acid oxidation. The mass activity of $\mathrm{Pd}_{3} \mathrm{Cu}_{1} / \mathrm{CNTs}$ is $238 \mathrm{~A} \mathrm{~g}^{-1}$, and that of $\mathrm{Pd}_{1} \mathrm{Cu}_{1} / \mathrm{CNTs}$ is $270 \mathrm{~A} \mathrm{~g}^{-1}$. The activities of these two samples were lower than that of $\mathrm{Pd} / \mathrm{CNTs}$. To further confirm the activities of the $\mathrm{Pd}_{1} \mathrm{Cu}_{3} / \mathrm{CNTs}$ and $\mathrm{Pd} / \mathrm{CNTs}$ catalysts, chronoamperometry tests were conducted in $0.5-\mathrm{M} \mathrm{H}_{2} \mathrm{SO}_{4}$ and $0.5-\mathrm{M}$ $\mathrm{HCOOH}$ at $0.15 \mathrm{~V}$ for $3600 \mathrm{~s}$. As shown in Fig.4B, during the first $1000 \mathrm{~s}$, the mass activities of $\mathrm{Pd}_{1} \mathrm{Cu}_{3} / \mathrm{CNTs}, \mathrm{Pd} / \mathrm{CNTs}, \mathrm{Pd}_{3} \mathrm{Cu}_{1} / \mathrm{CNTs}$, and $\mathrm{Pd}_{1} \mathrm{Cu}_{1} / \mathrm{CNTs}$ were $17.7 \mathrm{~A}$ $\mathrm{g}^{-1}, 11.0 \mathrm{~A} \mathrm{~g}^{-1}, 6.9 \mathrm{~A} \mathrm{~g}^{-1}$, and $2.1 \mathrm{~A} \mathrm{~g}^{-1}$, respectively. After $1000 \mathrm{~s}$, the mass activities of the four samples stabilized, and that of $\mathrm{Pd}_{1} \mathrm{Cu}_{3} / \mathrm{CNTs}$ remained higher than those of the others.

The electrochemical activity surface area (EASA) is one of the important standards for catalysts. Typically, CO-stripping measurements are used to estimate the 
EASA of Pd-based catalysts. The specific EASA was calculated according to the following equation:

$$
\mathrm{EASA}=\mathrm{Q} /(m C)
$$

where $Q$ is the charge for CO-desorption electrooxidation, $m$ is the Pd loading amount, and $C$ is the charge needed for the adsorption of a $\mathrm{CO}$ monolayer $(\mathrm{C}=420 \mu \mathrm{C}$ $\left.\mathrm{cm}^{-2}\right)$.

The EASA values are $38.4 \mathrm{~m}^{2} \mathrm{~g}^{-1}$ for Pd/CNTs, $32.5 \mathrm{~m}^{2} \mathrm{~g}^{-1}$ for $\mathrm{Pd}_{1} \mathrm{Cu}_{3} / \mathrm{CNTs}$, $31.7 \mathrm{~m}^{2} \mathrm{~g}^{-1}$ for $\mathrm{Pd}_{1} \mathrm{Cu}_{1} / \mathrm{CNTs}$, and $29.8 \mathrm{~m}^{2} \mathrm{~g}^{-1}$ for $\mathrm{Pd}_{3} \mathrm{Cu}_{1} / \mathrm{CNT}$. The specific area values were calculated in terms of the ratio of the mass activity and EASA. The specific activities of $\mathrm{Pd} / \mathrm{CNTs}, \mathrm{Pd}_{1} \mathrm{Cu}_{3} / \mathrm{CNTs}, \mathrm{Pd}_{1} \mathrm{Cu}_{1} / \mathrm{CNTs}$, and $\mathrm{Pd}_{3} \mathrm{Cu}_{1} / \mathrm{CNTs}$ are 12.7 $\mathrm{A} \mathrm{m}^{2}, 17.2 \mathrm{~A} \mathrm{~m}^{2}, 8.5 \mathrm{~A} \mathrm{~m}^{2}$, and $8.0 \mathrm{~A} \mathrm{~m}^{2}$, respectively. These values confirm the enhanced electrocatalytic activity of $\mathrm{Pd}_{1} \mathrm{Cu}_{3} / \mathrm{CNTs}$.

Previous reports have addressed the preparation of $\mathrm{Pd}-\mathrm{Cu}$ bimetallic catalysts. $\mathrm{Cu}$ has been used to modify the $\mathrm{Pd}$ crystalline structure and surface electronic properties by forming alloy phases [12,17]. For example, Park[17] reported the generation of $\mathrm{Pd}-\mathrm{Cu} / \mathrm{C}$ catalysts with high electrocatalytic activity via chemical dealloying, which resulted in a porous dealloyed structure. Lu and co-workers[12] described a preparation method similar to that presented here, involving impregnation-reduction with $\mathrm{NaBH}_{4}$ as a reductant. They found that a $\mathrm{Pd}-\mathrm{Cu} / \mathrm{C}$ catalyst with an atomic ratio of 3:1 exhibited the best electrocatalytic performance. In contrast, in this work, the $\mathrm{Pd}_{1} \mathrm{Cu}_{3} / \mathrm{CNTs}$ catalyst exhibited high electrocatalytic 
activity for formic acid oxidation, which can be attributed to the geometrical isolation of Pd neighbouring atoms by introducing foreign metals in formed alloy NPs.

To modify the strengths of adsorption and desorption on Pd surfaces, Pd can be modified through the formation of intermetallics or alloys. In comparison to the dispersion difficulty of intermetallics caused by high temperature annealing treatments, the low-temperature synthesis of alloys facilitates obtaining nanoscale dispersions on supporting materials. In the current work, the surface functionalities identified on CNTs gave rise to an anchoring effect toward salt precursors. After the metal ions were coordinated with functional groups, hydrolysis was applied to crystallize the precursors nucleated on the oxidized carbon supports and generate nanocrystals[18,19]. During the synthesis, the aggregation of reduced Pd precursors via Ostwald ripening was hindered by interactions between Pd species and the CNTs surface functionalities[20]. The obtained Pd NPs were applied as anchoring sites for alloying reduced $\mathrm{Cu}$ via spill-over effect. The increased $\mathrm{Cu}$ peak in the XPS spectra in comparison to the other catalysts indicates that reduced Pd in its metallic phase caused the spill-over effect and directed the adsorbed $\mathrm{H}_{2}$ to completely reduce the enriched amount of $\mathrm{Cu}$. After integrating with $\mathrm{Pd}$, the enriched $\mathrm{Cu}$ isolates $\mathrm{Pd}$ neighbouring atoms on $\mathrm{Pa}-\mathrm{Cu}$ alloy NPs. In this work, because of the strong driving force for the dissolution of $\mathrm{Cu}$ in $\mathrm{Pd}, \mathrm{Pd}-\mathrm{Cu}$ bimetallic phases may have formed in the $\mathrm{Pd}_{1} \mathrm{Cu}_{3}$ NPs after calcination and hydrogenation treatments. Meanwhile, $\mathrm{Pd}$ is segregated by $\mathrm{Cu}$ and remained in the metallic phase in the Pd-Cu alloy NPs. Accordingly, the adsorption strength of the $\mathrm{COOH}$ intermediate is relatively weak on 
nanosized Pd surfaces, thereby increasing the rate of formic acid oxidation to $\mathrm{CO}_{2}$ (and the associated oxidation current).

\section{Conclusions}

In this work, we prepared $\mathrm{Pd}_{\mathrm{x}} \mathrm{Cu}_{\mathrm{y}} / \mathrm{CNTs}$ catalysts with different atomic ratios through a simple impregnation method. The $\mathrm{Pd}_{\mathrm{x}} \mathrm{Cu}_{\mathrm{y}} / \mathrm{CNTs}$ catalysts with different $\mathrm{Pd}: \mathrm{Cu}$ atomic ratios exhibited markedly effect different for formic acid electrooxidation performances. During the deliberate thermal annealing treatments, carbon supports with surface functionalities were applied as substrates to crystallize the ion precursors and tune the nanoscale morphologies of the obtained $\mathrm{Pd}-\mathrm{Cu}$ alloy NPs. The enhanced electrocatalytic activity and stability of $\mathrm{Pd}_{1} \mathrm{Cu}_{3} / \mathrm{CNT}$ s catalyst can be attributed to the geometrical isolation of Pd neighbouring atoms by introducing foreign metals in formed alloy NPs.

\section{Acknowledgements}

This work is supported by the National Natural Science Foundation of China (21403137).

\section{References}

[1]. N. V. Rees, R. G. Compton, Sustainable energy: a review of formic acid electrochemical fuel cells. Journal of Solid State Electrochemistry 15(2011) 2095-2100.

[2]. O. Winjobi, Z. Zhang, C. Liang, W. Li, Carbon nanotube supported platinum-palladium nanoparticles for formic acid oxidation. Electrochimica Acta 55(2010) 4217-4221.

[3]. Y. Zhou, J. Liu, J. Ye, Z. Zou, J. Ye, J. Gu, T. Yu, A. Yang, Poisoning and regeneration of $\mathrm{Pd}$ catalyst in direct formic acid fuel cell. Electrochimica Acta 55(2010) 5024-5027.

[4]. M.M. Tusi, N.S.O. Polanco, S.G. Silva, E.V. Spinacé, A.O. Neto, The high activity of $\mathrm{PtBi} / \mathrm{C}$ electrocatalysts for ethanol electro-oxidation in alkaline medium. Electrochemistry Communications 13(2011)143-146. 
[5]. R.T. Lv, T.X. Cui, M.S. Jun, Q. Zhang, A.Y. Cao, D.S. Su, Z.J.Zhang, S.H. Yoon, J. Miyawaki, I. Mochida,F.Y. Kang, Open-ended, N-doped carbon nanotube-graphene hybrid nanostructures as high-performance catalyst support. Advanced Functional Materials 21(2011)999-1006.

[6]. Z. Liu, L. Hong, M. P. Tham, T. H. Lim, H. Jiang, Nanostructured Pt/C and Pd/C catalysts for direct formic acid fuel cells. Journal of Power Sources 161(2006) 831-835.

[7]. V. Mazumder, S. Sun, Oleylamine-mediated synthesis of Pd nanoparticles for catalytic formic acid oxidation. Journal of the American Chemical Society 131(2009) 4588-4589.

[8]. R. Wang, S. Liao, S. Ji, High performance Pd-based catalysts for oxidation of formic acid. Journal of Power Sources 180(2008) 205-208.

[9]. G.J. Zhang, Y. Wang, X. Wang, Y. Chen, Y.M. Zhou, Y.W. Tang, L. Lu, J.C. Bao, T.H. Lu, Preparation of $\mathrm{Pd}-\mathrm{Au} / \mathrm{C}$ catalysts with different alloying degree and their electrocatalytic performance for formic acid oxidation. Applied Catalysis B: Environmental 102(2011) 614-619.

[10]. X. Wang, Y. Tang, Y. Gao, T. Lu, Carbon-supported Pd-Ir catalyst as anodic catalyst in direct formic acid fuel cell. Journal of Power Sources 175(2008) 784-788.

[11]. R. Villa, D. Wang, P. Spontoni, R. Arrigo, D.S. Su, L. Prati, Nitrogen functionalized carbon nanostructures supported $\mathrm{Pd}$ and $\mathrm{Au}-\mathrm{Pd}$ NPs as catalyst for alcohols oxidation. Catalysis Today 157(2010) 89-93.

[12]. L. Lu, L. Shen, Y. Shi, T. Chen, G. Jiang, C. Ge, Y. Tang, Y. Chen, T. Lu, New insights into enhanced electrocatalytic performance of carbon supported $\mathrm{Pd}-\mathrm{Cu}$ catalyst for formic acid oxidation. Electrochimica Acta 85(2012) 187-194.

[13]. K. Mandal, D. Bhattacharjee, P. S. Roy, S. K. Bhattacharya, S. Dasgupta, Room temperature synthesis of $\mathrm{Pd}-\mathrm{Cu}$ nanoalloy catalyst with enhanced electrocatalytic activity for the methanol oxidation reaction. Applied Catalysis A: General 492(2015) 100-106.

[14]. W. Gao, N. Guan, J. Chen, X. Guan, R. Jin, H. Zeng, Z. Liu, F. Zhang, Titania supported $\mathrm{Pd}-\mathrm{Cu}$ bimetallic catalyst for the reduction of nitrate in drinking water. Applied Catalysis B: Environmental 46(2003) 341-351.

[15]. R. Prins, Hydrogen spillover. Facts and fiction. Chemical reviews 112(2012) 2714-38.

[16]. W. C. Conner, J. L. Falconer, Spillover in heterogeneous catalysis. Chemical reviews 95(1995) 759-788.

[17]. K.H. Park, Y. W. Lee, S.W. Kang, S.W. Han, A facile one-pot synthesis and enhanced formic acid oxidation of monodisperse $\mathrm{Pd}-\mathrm{Cu}$ nanocatalysts, Chemistry An Asian Journal 6(2011) 1515 - 1519.

[18] C. Batchelor-McAuley, L.D. Shao, G.G. Wildgoose, M.L.H. Green, R.G. Compton, An electrochemical comparison of manganese dioxide microparticles versus [small alpha] and [small beta] manganese dioxide nanorods: mechanistic and electrocatalytic behaviour, New Journal of Chemistry 32 (2008) 1195-1203. 
[19] X. Huang, L.D. Shao, G.W. She, M. Wang, S. Chen, X.M. Meng, Catalyst-free synthesis of single crystalline $\mathrm{ZnO}$ nanonails with ultra-thin caps, CrystEngComm 14 (2012) 8330-8334.

[20] L.D. Shao, X. Huang, D. Teschner, W. Zhang, Gold supported on graphene oxide: An active and selective catalyst for phenylacetylene hydrogenations at low temperatures, ACS Catalysis 4 (2014) 2369-2373.

\section{Figure captions}

Figure 1. (a) STEM image of $\mathrm{Pd}_{1} \mathrm{Cu}_{3} / \mathrm{CNT}$. (b) HRTEM image of a Pd-Cu alloy NP on the $\mathrm{Pd}_{1} \mathrm{Cu}_{3} / \mathrm{CNT}$. (c) STEM image of a dispersed Pd-Cu alloy NPs on the $\mathrm{Pd}_{1} \mathrm{Cu}_{3} / \mathrm{CNT}$. (d) and (e) STEM-EDX element mapping distributions of $\mathrm{Pd}$ and $\mathrm{Cu}$, respectively.

Figure 2. XRD patterns of the synthesized (a) $\mathrm{Cu}$, (b) $\mathrm{Pd}_{1} \mathrm{Cu}_{3}$, (c) $\mathrm{Pd}_{1} \mathrm{Cu}_{1},(\mathrm{~d}) \mathrm{Pd}_{3} \mathrm{Cu}_{1}$, and (e) Pd NPs. The black and red line represents $\mathrm{Cu}$ and PdCu standard in JCPDS, respectively.

Figure 3. XPS spectra of (A) $\mathrm{Pd} 3 \mathrm{~d}$ : (a) $\mathrm{Pd}_{1} \mathrm{Cu}_{3}$, (b) $\mathrm{Pd}_{1} \mathrm{Cu}_{1}$, (c) $\mathrm{Pd}_{3} \mathrm{Cu}_{1}$, and (d) $\mathrm{Pd}$; and (B) Cu2p: (a) Cu, (b) $\mathrm{Pd}_{1} \mathrm{Cu}_{3}$, (c) $\mathrm{Pd}_{1} \mathrm{Cu}_{1}$, and (d) $\mathrm{Pd}_{3} \mathrm{Cu}_{1}$.

Figure 4. (A) CVs of catalysts in $0.5-\mathrm{M} \mathrm{H}_{2} \mathrm{SO}_{4}$ and $0.5-\mathrm{M} \mathrm{HCOOH}$ at a scan rate of $50 \mathrm{mVs}^{-1}$. (B) Chronoamperometry curves of catalyst samples in $0.5-\mathrm{M} \mathrm{H}_{2} \mathrm{SO}_{4}$ and 0.5-M HCOOH. (a) $\mathrm{Pd}_{1} \mathrm{Cu}_{3} / \mathrm{CNTs}$, (b) Pd/CNTs, (c) $\mathrm{Pd}_{3} \mathrm{Cu}_{1} / \mathrm{CNTs}$, and (d) 
$\mathrm{Pd}_{1} \mathrm{Cu}_{1} /$ CNTs. 